\title{
Successful prophylaxis of experimental streptococcal endocarditis with single doses of sublethal concentrations of penicillin
}

\author{
P. Francioli and M. P. Glauser \\ Division des Maladies Infectieuses, Département de Médecine, \\ Centre Hospitalier Universitaire Vaudois, 1011 Lausanne, Switzerland
}

\begin{abstract}
Penicillin prophylaxis against expenmental endocarditıs due to a strain of Streptococcus intermedius isolated from a patient with endocarditis was studied in rats. The minimum bactericidal concentration of penicillin for thıs strain was more than $64 \mathrm{mg} / \mathrm{l}$ and was higher than the peak penicillin serum level obtanned in rats $30 \mathrm{~min}$ after the $1 \mathrm{v}$ injection of $60 \mathrm{mg} / \mathrm{kg}$, and in man after an oral dose of $2 \mathrm{~g}$ of phenoxymethyl penicillın. Moreover timed kill curves performed in the presence of $64 \mathrm{mg} / \mathrm{l}$ of penicillin showed no decrease in the number of colony-forming units during the first $6 \mathrm{~h}$ of incubation and only a $95 \%$ decrease after $24 \mathrm{~h}$. In addition, no bactericidal activity could be detected in the serum 30 mın after penıcillin injection, that is at the time of bacterial challenge. Using the minimum bacternal inoculum needed to produce endocarditıs in $90 \%$ of control animals (ID 90 ) penicillın successfully prevented endocarditis due to this strain. We conclude that penicillin may prevent streptococcal endocarditis by other mechanısms than bacterial killing.
\end{abstract}

\section{Introduction}

Penicillin is one of the most commonly recommended antibiotics for prophylaxis of bacterial endocarditis in susceptuble patients undergoing oral procedures. Studies in the rabbit model of endocarditis have suggested that high and repeated doses of bactericidal antibiotics, including penicillin, were necessary to achieve successful protection (Durack \& Petersdorf, 1973; Pelletier, Durack \& Petersdorf, 1975) Furthermore, antibiotics like clindamycin or tetracycline were ineffective, suggestıng that bacterial kılling was the main mechanism by which antıbıotics protected against endocarditis. However the number of micro-organisms used to induce infection in these experiments was very high and probably greatly exceeded that found in man after dental manipulation.

Recent experiments performed with lower inocula have shown that single doses of vancomycin, amoxicillin and even "bacteriostatic" antibiotics such as clindamycin or erythromycin were effective in preventing endocarditis (Bernard, Francioli \& Glauser, 1981; Glauser \& Francioli, 1982; Glauser et al., 1983a). These studies raised the possibılity of mechanisms other than bacterial killing operatıng to prevent endocarditıs, since protection was achieved in the absence of bactericidal actıvity of the antıbiotics used for prophylaxis.

Mechanisms of action other than bacterial kıllıng are not only interesting but highly desirable if one considers that up to 40 to $50 \%$ of Streptococcus virldans isolated either 
from the mouth flora (Dankert \& Hess, 1982) or from patients with endocarditis (Glauser et al., 1983b) were shown to be tolerant to penicillin or amoxicillin.

The purpose of the present study was to test the efficacy of penicillin, the antibiotic most commonly used for endocarditis prophylaxis, against a strain of Str. viridans highly resistant to its bactericidal activity.

\section{Material and methods}

\section{Micro-organism}

A previously described strain of Str. intermedius isolated from a patient with bacterial endocarditis was used (Glauser \& Francioli, 1982). Minimal inhibitory concentration (MIC) of penicillin were determined by broth dilution tests, using Mueller-Hinton broth (Difco Laboratories, Detroit, U.S.A.), and $5 \times 10^{5} \mathrm{cfu}$ as the inocula. The minimal bactericidal concentration (MBC) were determined by subculturing on penicillinasecontaining blood agar plates $0-1 \mathrm{ml}$ of an undiluted sample. After incubation for $48 \mathrm{~h}$ the number of colonies on each plate was counted, and the $\mathrm{MBC}$ was determined as the lowest dilution of antibiotic that showed $99.9 \%$ killing.

Killing curve with $64 \mathrm{mg} / \mathrm{l}$ of penicillin were performed in trypticase soya broth (Difco Laboratories, Detroit, U.S.A.) using an inoculum of $10^{6} \mathrm{cfu} / \mathrm{ml}$ of an overnight culture of Str. intermedius. This concentration was chosen because it was well above achievable serum levels obtainable in humans after a $2 \mathrm{~g}$ oral dose of phenoxymethyl penicillin.

\section{Penicillin serum levels and serum bactericidal activity}

Serum levels of sodium benzyl penicillin were determined in five rats by an agar diffusion technique (Sabath \& Anhalt, 1980) at $30 \mathrm{~mm}, 1$ and $2 \mathrm{~h}$ after iv injection of $60 \mathrm{mg} / \mathrm{kg}$. This dosage was chosen because it produces peak serum levels in rats similar to those achieved in man after an oral dose of $2 \mathrm{~g}$ of phenoxymethyl penicillin. The serum bactericidal activity of penicillin against Str. intermedius was determined by standard methods (Anhalt, Sabath \& Barry, 1980) 30 min after iv injection of $60 \mathrm{mg}$ of penicillin $/ \mathrm{kg}$ of body weight. The serum bactericidal activity was defined as the highest serum dilution that gave $99.9 \%$ killing after $24 \mathrm{~h}$ of incubation.

\section{Production and prophylaxis of endocarditis}

Sterile vegetations were produced in femal Wistar rats (weight $180-200 \mathrm{~g}$ ) by a modification of a previously described method. In brief, a polyethylene catheter (model no. PP10; Portex, Hythe, Kent, England) was passed through the aortic valve via the right carotid artery and secured with a silk ligature. Twenty-four hours after catheterization, rats were injected in the tail vein with saline or $60 \mathrm{mg} / \mathrm{kg}$ of sodium penicillin. Thirty minutes later $0.5 \mathrm{ml}$ of saline containing $10^{5} \mathrm{cfu}$ of bacteria, the minimal inoculum needed to produce endocarditis in more than $90 \%$ of control rats, was injected intravenously (Glauser et al., 1983a). Rats were killed $72 \mathrm{~h}$ after bacterial challenge, and aortic vegetations were excised, weighed, homogenized in $1 \mathrm{ml}$ of $0.85 \%$ $\mathrm{NaCl}$, serially diluted, and plated. Colony counts were done after $48 \mathrm{~h}$ of incubation at $37^{\circ} \mathrm{C}$. 


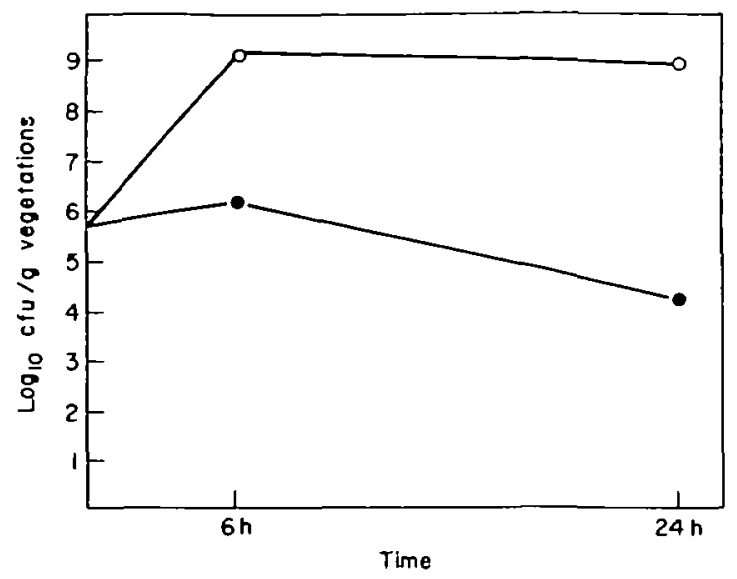

Figure 1. Rate of in-vitro kjlling of Str intermedius by $64 \mathrm{mg}$ of penucllin/l a concentration 4 tumes higher than the serum level in rats $30 \mathrm{~min}$ after the iv injection of $60 \mathrm{mg} / \mathrm{kg}$ of pensillin 0 , Control; penicillin $64 \mathrm{mg} /$

\section{Statistical analysis}

The $\chi^{2}$ test with Yates's correction was used for statistical comparisons.

\section{Results}

Susceptibility of Str. intermedius to penicillin

Minimal inhibitory and bactericidal concentrations for the Str. intermedius of penicillin were 0.032 and $>64 \mathrm{mg} / 1$ respectively. Survival of Str. intermedius in $64 \mathrm{mg} / \mathrm{l}$ of penicillın showed no decrease in cfu during the first $6 \mathrm{~h}$ of incubation and only a $90-99 \%$ killing after 24 and $48 \mathrm{~h}$ of incubation (Figure 1). Therefore, this Str. intermedius was tolerant to the bactericidal action of penıcillin.

\section{Penicillin serum levels and serum bactericidal activity (Figure 2)}

Penicillin serum levels ( \pm S.D.) in 5 rats $30 \mathrm{~min}, 1 \mathrm{~h}$ and $2 \mathrm{~h}$ after injection of $60 \mathrm{mg} / \mathrm{kg}$ iv were $16 \pm 1,2 \pm 0.1$ and approximately $0.01 \mathrm{mg} / \mathrm{l}$, respectively. There was no detectable serum bactericidal activity $30 \mathrm{~min}$ after injection of penicillin, that is at the tıme of injection of bacteria in the prophylaxis experiments.

Prophylaxis of Str. intermedius endocarditis by intravenously administered penicillin (Figure 3)

The incidence of Str. intermedius endocarditis was reduced from $95 \%(22 / 23$ rats) in controls to $20 \%(4 / 20)$ in rats given penicilln $30 \mathrm{~min}$ before bacterial challenge $\left(P<10^{-4}\right)$.

\section{Discussion}

Earlier studies in rabbits have shown that high and prolonged serum levels of bactericıdal antıbıotics, including penicillin, were necessary for adequate prophylaxis 


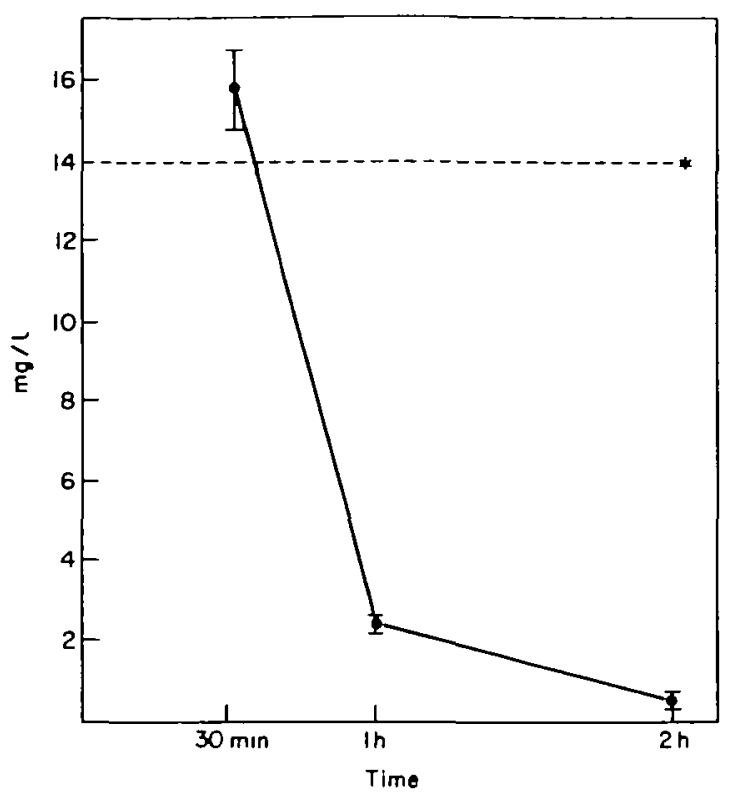

Figure 2. Serum levels $( \pm S \mathrm{D})$ of sodium penicillin $30 \mathrm{~min}, 1 \mathrm{~h}$ and $2 \mathrm{~h}$ after a single iv injection of $60 \mathrm{mg} / \mathrm{kg}$ in rats The dotted line represents peak level achieved in humans after an oral dose of $2 \mathrm{~g}$ of phenoxymethyl penıcillın

against Str. viridans endocarditis (Durack \& Petersdorf, 1973).

Recently, strains of viridans streptococci isolated from the oral flora of children with cardiac disease (Dankert \& Hess, 1982) and from their blood after dental extractions (Holloway, Dankert \& Hess, 1980) were often shown to be tolerant to penicillin. In addition, we found that 17 out of 25 strains of viridans streptococci isolated from patients with endocarditss were tolerant to amoxicillin, 13 of them having MBCs

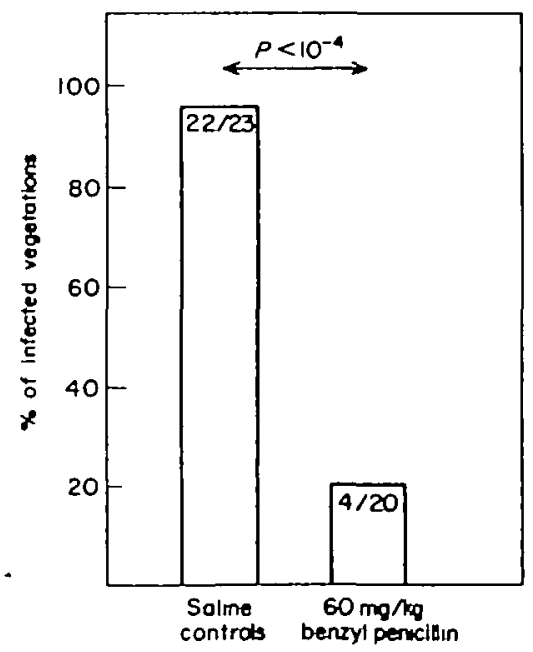

Figure 3. Incidence of endocarditus due to Str. intermedius after prophylaxis with $60 \mathrm{mg} / \mathrm{kg}$ of sodium penicillin administered iv $30 \mathrm{~min}$ before bactenal chalkenge. Numbers within the bars indicate the number of rats in each group 
greater than $32 \mathrm{mg} / \mathrm{l}$, a concentration which is higher than the peak serum levels achieved after a $3 \mathrm{~g}$ oral dose (Glauser et al., 1983b).

To assess whether the phenomenon of in-vitro tolerance holds any significance in vivo, Hess, Dankert \& Durack (1983) studied the ability of penicillin to prevent experimental endocarditis caused by tolerant and non-tolerant strains of Str. sanguis. They found that a single dose of penicillin was successful when the strain of streptococcus was highly sensitive to the bactericidal action of the antibiotic, but was much less effective when the strains were tolerant and not killed in vitro by concentrations of penicillin similar to those achieved in vivo. Moreover the efficacy of penicillin against tolerant strains were greatly increased by the addition of streptomycin which provided a better bactericidal activity. These results were interpreted as showing that killing was indeed a critical factor for efficacy of prophylaxis and, because of the occurrence of tolerance among viridans streptococci, this raises concern about the efficacy of the single dose amoxicillin regimen recently recommended by the Working Party of the British Society for Antimicrobial Chemotherapy (1982).

In contrast to the expenments mentioned above (Durack and Petersdorf, 1973; Hess, Dankert and Durack 1983), we and others recently found that single doses of vancomycin (Bernard et al., 1981; Scheld et al., 1981), amoxicillin (Glauser et al., 1983a) and even bacteriostatic antibiotics (Glauser \& Franciol, 1982) could afford excellent protectıon against Str. viridans endocarditis in the absence of bacterial killing. With the present study, penicillin can be added to the list of antibiotic operating in the absence of bacterial killing. Indeed, the Str. intermedius strain had a MBC for penicillin much higher than the peak serum level of the antibiotic and therefore was not expected to be killed by the drug in vivo. This was also attested by the killing curves and the absence of any detectable bactericidal activity in the serum at the time of injection of the bacteria.

The discrepancy between the present results and those of Durack \& Petersdorf (1973) and Hess et al. (1983) regarding the requirement for penicillin to be bactericidal in order to prevent endocarditis might be explained by the differences in the size of the inocula used for bacterial challenge. Indeed, we have shown in rats that streptococcal endocarditis can be efficiently prevented by single doses of non-bactericidal concentrations of amoxicillin, provided that, like in the present experiment, the inoculum size is not higher than the minimum inoculum able to induce endocarditis in $90 \%$ of control animals (ID 90 ). With higher inocula the efficacy of prophylaxis of amoxicillin was abolished unless the strain of streptococcus used was highly sensitive to the bactericidal action of the drug (Glauser et al., 1983a). Therefore, a bactericidal activity appears to be required for efficient prophylaxis only when infection is induced by inocula 10 or 100 times higher than the ID $_{90}$. Durack \& Petersdorf (1973) used an inoculum of $10^{8} \mathrm{cfu}$ and presented evidence that this inoculum was much higher than the ID 90 (Pelletier, Durack \& Petersdorf, 1975). Hess, Dankert \& Durack (1983) used an inoculum of $10^{7} \mathrm{cfu}$, a size which is likely to be also above the $\mathrm{ID}_{\mathbf{9 0}}$. In contrast, the present experiments using penicillin as prophylactic antibiotic were carried out with an inoculum known to be close to the $\operatorname{ID}_{90}$ (Glauser et al., 1983a). These differences in inoculum size probably explain why, in the absence of killing, penicillin prevented endocarditis in the present experiment, while it did not in other studies. Even though the inoculum we used was smaller, it provides a stringent test of antibiotic prophylaxis because the resulting bacteraemia is far greater than that observed in humans after 
oral procedure (Petersdorf, 1978) and produces $80-100 \%$ endocarditis in animals.

The mechanisms by which antibiotics can prevent endocarditis in the absence of killing are not completely elucidated. The cell-wall active antibiotics such as penicillin, amoxicillin or vancomycin have been shown in vitro to interfere with streptococcal adhesiveness to platelets fibrin matrices mimiking cardiac vegetations. Moreover there are in-vivo experimental suggestions that inhibition of adherence might be one of the mechanisms of action of antibiotics involved in endocarditis prophylaxis. (Scheld et al., 1981; Lowy et al., 1983; Glauser et al., 1983a).

Whatever the mechanism of protection, the present experiment demonstrates that short-lived serum levels of penicillin similar to those achieved in man after an oral dose of $2 \mathrm{gm}$ of phenoxymethyl penicillin can efficiently prevent the development of endocarditis, provided the bacterial inoculum size used for challenge is limited to the ID 9 .

\section{References}

Anhalt, J. P., Sabath, L. D. \& Barry, A. L. (1980) Special tests: bactericidal actıvity, actıvity of antimicrobics in combination, and detection of $\beta$-lactamase production. In Manual of Clinical Microbiology 3rd edn. (Lennette, E H., Blows, A., Hausler, W. J. Jr. \& Truant, J. P. Eds), pp 478-84. American Society for Microbiology, Washington, D.C.

Bernard, J. P., Francioli, P \& Glauser, M. P. (1981). Vancomycin prophylaxis of experimental streptococcus sanguis endocarditis: inhibition of bacterial adherence rather than bactenal killing. Journal of Clunical Investigation 68, 1113-5.

Dankert, J. \& Hess, J. (1982). Penicillin-sensitive streptococcal endocarditss. Lancet ii, 1219.

Durack, D T \& Petersdorf, R. G (1973). Chemotherapy of experimental streptococcal endocarditis. I. Comparison of commonly recommended prophylactic regımens Journal of Clinical Investigation 52, 592-8.

Glauser, M. P. \& Francioli, P (1982). Successful prophylaxis against experimental streptococcal endocarditis with bactenostatic antibiotics. Journal of Infectious Diseases 146, 806-10.

Glauser, M. P., Bernard, J. P., Moreillon, P \& Francioli P. (1983a). Successful single-dose amoxicillın prophylaxis against experimental streptococcal endocarditıs: Evidence for two mechanisms of protection. Journal of Infectious Dusease 147, 568-75.

Glauser, M. P, Francioli, P., Meylan, P., Moreıllon, Ph. \& Heraief E. (1983b). Antibiotic prophylaxis for patients with prosthetic valves. Lancet $1,237-8$.

Hess, J., Dankert, J. \& Durack D. (1983). Signıficance of penicillin tolerance in vivo. prevention of expenmental Streptococcus sanguis endocarditis. Journal of Antimicrobial Chemotherapy $11,555-64$.

Holloway, Y., Dankert, J. \& Hess, J. (1980). Penicillın tolerance and bacterial endocarditus (letter). Lancet $i, 589$.

Lowy, F. D., Chang, D. S., Neuhaus, E. G, Horne, D S., Tomasz, A. \& Steigbigel, N. H. (1983). Effect of penicillin on the adherence of streptococcus sanguis in vitro and in the rabbit model of endocarditis. Journal of Clinical Investigation 71, 668-75.

Pelletier, L. L., Jr., Durack, D. T. \& Petersdorf, R. G. (1975). Chemotherapy of experimental streptococcal endocarditıs. IV. Further observations on prophylaxis. Journal of Clinical Investigation 56, 319-30

Petersdorf, R G. (1978). Antımicrobial prophylaxis of bacterial endocarditis: prudent caution or bacterial overkill? American Journal of Medicine 65, 220-3

Sabath, L. D. \& Anhalt, J. P. (1980). Assay of antimicrobics In Manual of Clinical Microbiology, 3rd edn. (Lennette, E. H., Blows, A., Hausler, W. J. Jr. \& Truant, J P, Eds), pp. 485-90. American Society for Microbiology, Washington, D.C.

Scheld, W. M., Zack, O., Vosbeck, K. \& Sande, M. A. (1981). Bactenal adhesion in the pathogenesis of infective endocarditis: effect of subınhibitory antibiotic concentrations on streptococcal adhesion in vitro and the development of endocarditis in rabbits. Journal of Clinical Investigation 68, $1381-4$

Workıng Party of the Bntısh Society for Antimicrobial Chemotherapy. (1982). The antibiotic prophylaxis of infective endocarditis. Lancet ii, 1323-6. 